\title{
Ornithine Transcarbamylase (OTC) in White Blood Cells
}

\author{
NORIYUKI NAGATA, IZUMI AKABOSHI, JIRO YAMAMOTO, ICHIRO MATSUDA, (19) \\ HIROSHI OHTSUKA, AND TAKATO KATSUKI \\ Department of Pediatrics, Department of Microbiology, Kumamoto University Medical School, 860 Kumamoto, Japan
}

\begin{abstract}
Summary
A radiochemical assay method of ornithine transcarbamylase (OTC) was developed using labeled carbamyl phosphate as a substrate. The enzyme activities determined by this method in peripheral white blood cells from ten normal subjects were 1.32 $\pm 0.95 \mathrm{nmoles} / \mathrm{mg} / \mathrm{hr}$ and the apparent $K_{\mathrm{m}}$ 's, when assayed at $\mathrm{pH}$ 8.5 , were $6.4 \mathrm{mM}$ for ornithine and $0.6 \mathrm{mM}$ for carbamyl phosphate. On the contrary, the apparent $K_{m}$ 's of human liver OTC were $0.6 \mathrm{mM}$ for ornithine and $0.12 \mathrm{mM}$ for carbamyl phosphate. The average OTC activity of granulocytes was $1.0 \mathrm{nmoles} / \mathrm{mg} / \mathrm{hr}$, whereas that of mononuclear cells was $0.4 \mathrm{nmoles} / \mathrm{mg} / \mathrm{hr}$.

Lymphoid cell lines were established from three normal subjects and an OTC-deficient infant. All these cell lines demonstrated no OTC activity. When arginine was removed from the medium and replaced by ornithine, the lymphoid cells were unable to grow in culture. On autoradiography, the lymphoid cells showed labeling at incubation in the presence of ${ }^{14} \mathrm{C}$-citrulline, but not with ${ }^{14} \mathrm{C}$ ornithine.
\end{abstract}

\section{Speculation}

The wide range of OTC activities observed in white blood cells from normal subjects might be due to a difference of the enzyme activities between granulocytes and mononuclear cells and in turn due to an individual difference of the two cell population.

OTC is either absent or inactivated in lymphoid cell lines, when grown in a culture medium with arginine. The enzyme of the peripheral white blood cells might be of a different genetic origin from that of the liver.

The diagnosis of inherited hyperammonemia has been made by measuring urea cycle enzymes in the liver $(3,4,10)$ and other organs. Wolfe and Gatfield (17) recently demonstrated the presence of ornithine transcarbamylase [EC 2.1.3.3] (OTC) as well as other urea cycle enzymes in peripheral white blood cells from normal subjects. OTC deficiency was diagnosed by using peripheral blood white cells from the patients with OTC deficiency (7, 17). On the other hand, Snodgrass et al. (15) recently reported that OTC deficiency in the liver can not be inferred from the measurements of the enzyme's activity in peripheral white blood cells because the latter parameter was normal in their patients.

All these studies were carried out using a colorimetric method that is designed to measure the amount of citrulline produced in the assay system. The colorimetric method has several disadvantages: (1) the color complex formed is relatively light sensitive; (2) diacetylmonoxime reacts with carbamide compounds other than citrulline which give a color reaction; (3) the narrow range of optical density, which is from 0.01 to 0.03 according to Wolfe and Gatfield (17), is another problem in measuring OTC activity in white blood cells.

The use of radiochemical assay method as suggested by Wolfe and Gatfield (17), appears to be preferable in view of the fact that the OTC activity is low in the peripheral white blood cells and that the sensitivity of the radiochemical method is higher than that of the colorimetric method.

We would like to describe a radiochemical assay method using ${ }^{14} \mathrm{C}$-carbamyl phosphate as a substrate and to discuss the presence of OTC activities in peripheral blood white cells and cultured lymphoid cells.

\section{MATERIALS}

L-Ornithine hydrochloride and carbamyl phosphate (dilithium salt) used were from Sigma Chemical Co., St. Louis, MO. ${ }^{14} \mathrm{C}$ carbamyl phosphate (dilithium salt), ${ }^{14} \mathrm{C}$-citrulline, and $\left[{ }^{14} \mathrm{C}\right]-$ ornithine were purchased from New England Nuclear, Boston, MA. All the other chemicals used were of reagent quality. It was found in a pilot study that recrystallization of ${ }^{/ 4} \mathrm{C}$-carbamyl phosphate is unnecessary. OTC from bovine liver, partially purified by the method of Marshall and Cohen (9), was kindly supplied by Professor Tachibana.

\section{METHOD}

\section{PREPARATION OF WHITE BLOOD CELL}

White blood cells were prepared by the modified method of Wolfe and Gatfield (17). Five volumes of freshly drawn blood were quickly mixed with one volume of solution containing 5\% dextran, $0.7 \% \mathrm{NaCl}$ solution, and $0.05 \%$ heparin. After standing for $\mathbf{4 5} \mathrm{min}$ at room temperature, the supernatant white blood cellrich layer was removed and centrifuged at $600 \times g$ at $4^{\circ} \mathrm{C}$. The pellets were washed with ice-cold isotonic saline. Residual red cells were removed by gently mixing the pellets with $5 \mathrm{ml}$ of distilled water for $60 \mathrm{sec}$. Five $\mathrm{ml}$ of $1.7 \% \mathrm{NaCl}$ solution was added, and the pellets were recovered by centrifugation at $\mathbf{4 0 0 0}$ $\times g$ at $3^{\circ} \mathrm{C}$.

Separation of mononuclear cells from the granulocytes was accomplished by differential flotation using a modified method of Boÿum (1).

\section{ESTABLISHMENT OF LYMPHOID CELL LINE}

Long-term lymphoid cell lines were established from normal subjects $(N=3)$ and an OTC-deficient infant after incubation with Epstein-Barr (EB) virus as described previously (11). The infant with OTC deficiency was diagnosed by measuring the enzyme activity in biopsy specimen of the liver.

\section{MEASUREMENT OF OTC ACTIVITY}

Cell pellets were suspended in $0.1 \%$ cetylpyridinium chloride, frozen and thawed three times, and centrifuged at $12,000 \times g$ for $25 \mathrm{~min}$. The clear supernatants were used in radiochemical assay. The radiochemical assay method used in study was a modification of the method (14) of Goldstein et al. (3), which measured the 
conversion rate of ${ }^{14} \mathrm{C}$-carbamyl phosphate. One hundred $\mu \mathrm{l}$ of the supernatant ${ }^{14} \mathrm{C}$-carbamyl phosphate (final concentration, 0.87 $\mathrm{mM}$; specific activity, $1.31 \times 10^{3} \mathrm{cpm} / \mathrm{nmole}$ ), and ornithine (final concentration, $5 \mathrm{mM}$ ) were mixed, and $0.05 \mathrm{M}$ triethanolamine acetic acid buffer, $\mathrm{pH} 8.5$, was added to make a total volume of 2 $\mathrm{ml}$. The mixture was incubated at $37^{\circ} \mathrm{C}$ for $60 \mathrm{~min}$ unless otherwise stated. The reaction was then terminated by adding $100 \mu \mathrm{l}$ of $3 \mathrm{~N}$ formic acid. After heating for $5 \mathrm{~min}$ in a boiling water bath, the excess ${ }^{14} \mathrm{CO}_{2}$ was removed by adding crushed dry ice. After centrifugation for $10 \mathrm{~min}$ at $2000 \times \mathrm{g}$, the supernatants were transferred to counting vials and evaporated to dryness under air suction, and $0.3 \mathrm{ml}$ of water and $5 \mathrm{ml}$ of Aquasol-2 (New England Nuclear) were added. ${ }^{14} \mathrm{C}$-Carbamyl phosphate incorporation was counted by Beckman liquid scintillation spectrometer. Boiled cell lysate was used as control blank material.

Apparent $\mathbf{K}_{\mathrm{m}}$ 's of OTC for ornithine and for carbamyl phosphate were obtained from Lineweaver-Burk plots.

Partially purified bovine liver OTC and human liver specimen obtained by surgical operation were used in a reference study. The enzyme activity was measured: (1) by a colorimetric method of Brown and Cohen (2); and (2) by a radiochemical assay. For the radiochemical assay, bovine OTC or crude homogenate of human liver (2) was diluted with distilled water and processed in the same manner as the cell lysates.

Protein was measured by the method of Lowry et al. (8).

\section{GROWTH CURVE OF LYMPHOID CELLS}

Lymphoid cells established from normal controls and the patient with OTC deficiency were cultured in two different media: (1) Roswell Park Memorial Institute medium 1640 (RPMI 1640) with $1 \mathrm{mM}$ arginine (ornithine-, arginine+); and (2) RPMI 1640 with 1 or $5 \mathrm{mM}$ ornithine substituted for arginine (ornithine+, arginine-). Total numbers of the cells were counted in a hemocytometer, and their viability was determined by trypan blue dye exclusion.

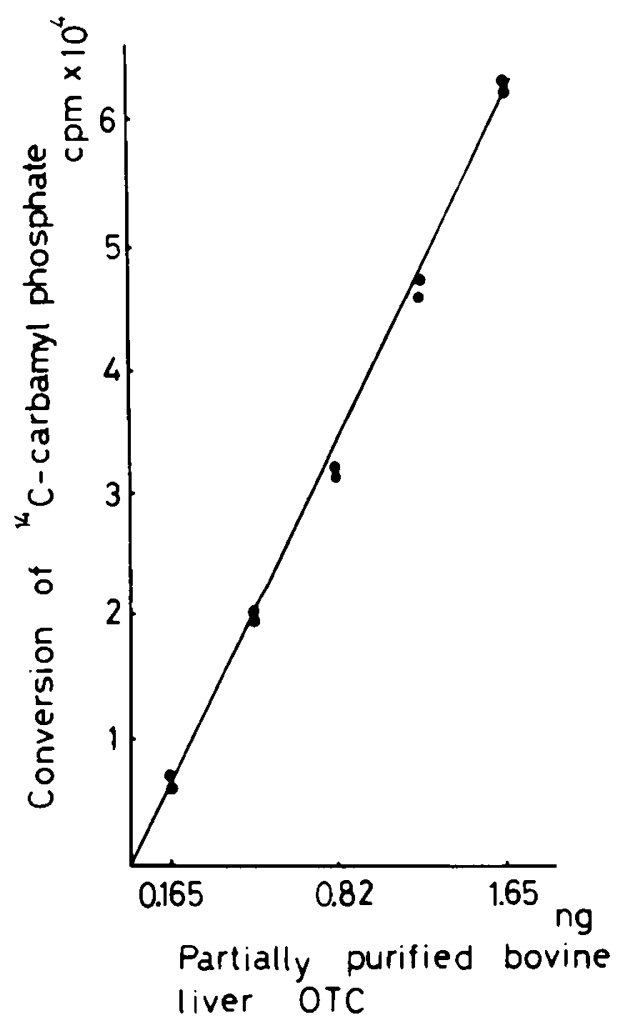

Fig. 1. Relationship of protein concentration of partially purified bovine liver OTC to the conversion of ${ }^{14} \mathrm{C}$-labeled carbamyl phosphate Reaction mixture was incubation for $10 \mathrm{~min}$.

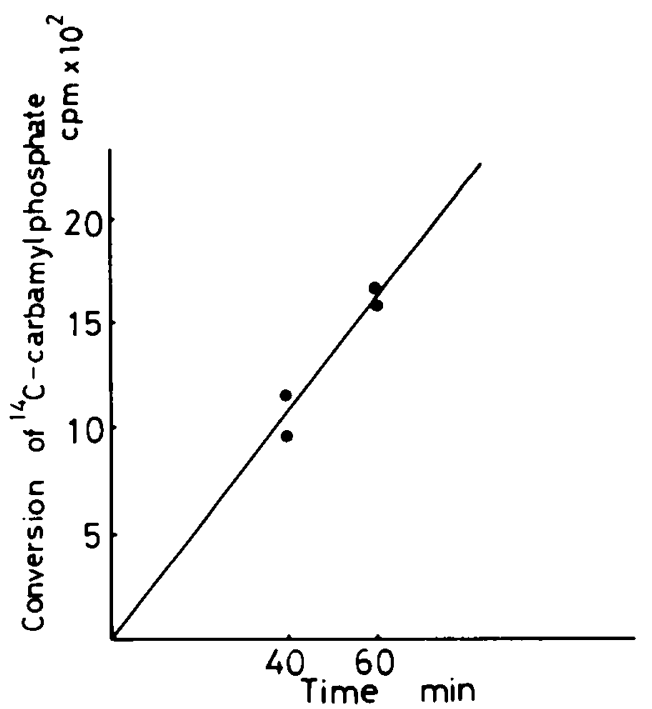

Fig. 2. Time course study of OTC activity in leukocyte lysate.

\section{AUTORADIOGRAPHY}

Logarithmically growing cells, each $5 \times 10^{5}$ in number from the OTC-deficient infant and control subjects were washed with arginine-free RPMI 1640 and incubated for $48 \mathrm{hr}$ at $37^{\circ} \mathrm{C}$ in RPMI 1640 , which contained ornithine $\left[1 \mathrm{mM}\right.$ of cold ornithine and ${ }^{14} \mathrm{C}$ ornithine $(1 \mu \mathrm{Ci} / \mathrm{ml})]$ or citrulline $[1 \mathrm{mM}$ of cold citrulline and ${ }^{14} \mathrm{C}$-citrulline $\left.(1 \mu \mathrm{Ci} / \mathrm{ml})\right]$ instead of arginine. After the incubation, cells were washed three times with Hanks' balanced salt solution and centrifuged at $1000 \mathrm{rpm}$. They were resuspended in fetal calf serum, placed on glass slides, and fixed with methanol. Slides were dipped in Kodak NTB3 emulsion, exposed for 5 days, developed in D-19 for $3 \mathrm{~min}$, and stained with Giemsa.

\section{RESULTS}

TIME COURSE STUDY AND REACTION KINETICS OF PARTIALLY PURIFIED BOVINE LIVER OTC

Colorimetry. Linearity was found between the incubation time and citrulline production rates and also between citrulline production rates and enzyme protein levels. The range of detectable activity by this method was from 75 to $300 \mathrm{ng}$ of enzyme protein.

Radiochemical Assay. Time course study was performed up to $40 \mathrm{~min}$ of incubation, and a positive linear relationship between the incubation time and the conversion rate of radioactive substrate was found. The relationship between the conversion rate of ${ }^{14} \mathrm{C}$-carbamyl phosphate and enzyme protein, measured after 20 min incubation, was also linear. The range of detectable activity by this method was from 0.16 to $1.6 \mathrm{ng}$ (Fig. 1). The mean enzyme activity obtained by the colorimetric method was approximately $13 \%$ higher than that obtained by the radiochemical assay.

APPARENT $K_{m}$ OF HUMAN LIVER OTC

Radiochemical assay was used in measurement of human liver OTC and obtained results are listed in Table 2.

TIME COURSE STUDY AND REACTION KINETICS OF OTC OF HUMAN PERIPHERAL WHITE BLOOD CELLS

Significant radioactivity could not be obtained at 20 min incubation due to scanty content of the enzyme in white blood cells. OTC activity was, therefore, determined at 40 and $60 \mathrm{~min}$ incubation. Longer incubation was not feasible because carbamyl phosphate is unstable in solution. Using (unfortunately) only two time points and extrapolating to zero time, a positive linear relationship was found between incubation time and conversion of ${ }^{14} \mathrm{C}$-carbamyl phosphate (Fig. 2). The relationship between the conversion rate of radioactive substrate and the amount of cell lysate, measured after $60 \mathrm{~min}$ incubation, was linear (Fig. 3). 
Results obtained and apparent $K_{m}$ of OTC for ornithine and carbamyl phosphate are shown in Tables $I$ and 2. OTC activity of granulocytes appeared to be approximately two times higher than that of mononuclear cells.

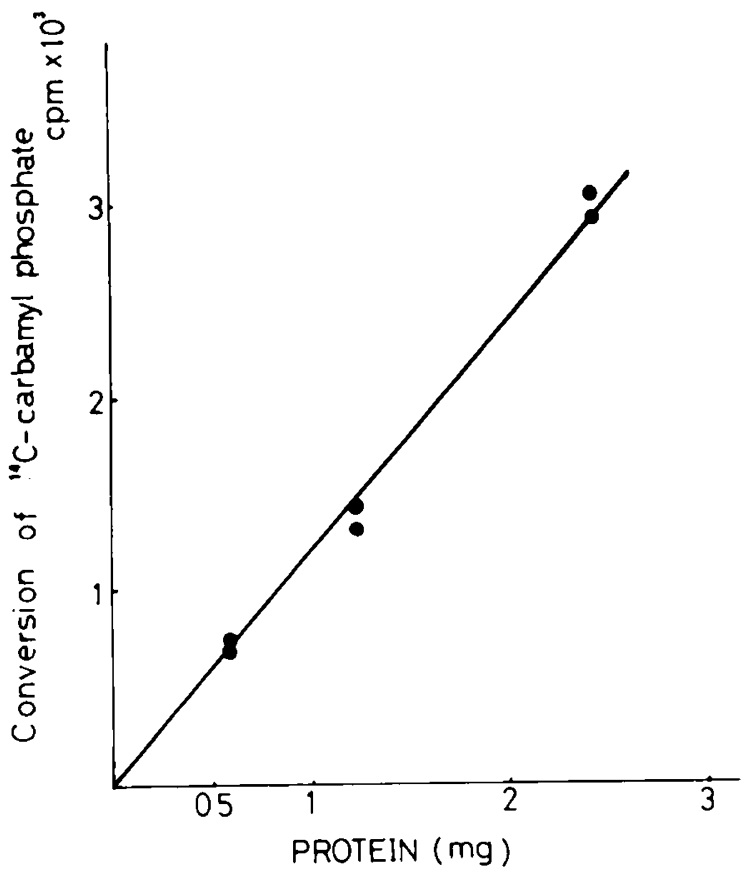

Fig. 3. Relationship of protein concentration of leukocyte lysate protein to OTC activity. Reaction mixture was incubated for $60 \mathrm{~min}$.

Table 1. Ornithine transcarbamylase in white blood cells and cultured lymphoid cells

\begin{tabular}{lcl}
\hline & $\begin{array}{c}\text { Mean } \pm \text { S.D. } \\
\text { (nmoles/mg } \\
\text { protein/hr) }\end{array}$ & \multicolumn{1}{c}{ Reference } \\
\hline $\begin{array}{c}\text { White blood cells } \\
(N=10)\end{array}$ & $1.32 \pm 0.95$ & Present study \\
$\begin{array}{c}\text { Granulocytes } \\
(N=2)\end{array}$ & 1.0 & \\
$\begin{array}{c}\text { Mononuclear cells } \\
(N=2)\end{array}$ & 0.4 & \\
$\begin{array}{c}\text { Cultured lymphoid cells } \\
(N=4)^{1}\end{array}$ & 0 & \\
$\begin{array}{c}\text { White blood cells } \\
(N=7)\end{array}$ & $128 \pm 67$ & $\begin{array}{c}\text { Wolfe } \text { et al. } \\
(17)\end{array}$ \\
$\begin{array}{c}\text { White blood cells } \\
(N=14)\end{array}$ & $\begin{array}{c}\text { Snodgrass } \text { et al. } \\
(15)\end{array}$ \\
\hline
\end{tabular}

'Including a sample derived from an OTC-deficient patient.
It was not possible to demonstrate by repeated measurements the enzyme activity in lymphoid cell lines derived from both the controls and the OTC-deficient patient.

\section{GROWTH CURVES}

Lymphoid cells from both the controls and the OTC-deficient infant showed normal logarithmic growths in the arginine $(+)$ ornithine $(-)$ medium, whereas the cells failed to grow in the arginine $(-)$ ornithine $(+)$ medium (Fig. 4), even when incubated for 40 days while changing medium every 3 days.

\section{AUTORADIOGRAPHY}

When incubated in the presence of ${ }^{14} \mathrm{C}$-ornithine, few grains were found on cultured lymphoid cells from both the normal subjects and the OTC-deficient patient. On the other hand, when ${ }^{14} \mathrm{C}$-citrulline was substituted for ${ }^{14} \mathrm{C}$-ornithine, more than $80 \%$ of cultured lymphoid cells contained more than 20 grains per cell.

\section{DISCUSSION}

Although the results are in conflict with that by Rabier et al. (13) who could not find the activity of OTC in white blood cells, our study clearly demonstrated the presence of OTC in white blood cells, as found by Wolf and Gatfield (17) and Snodgrass $e t$ al. (15). The enzyme levels obtained by our study were lower than those in the other studies. The discrepancy might be attributable to the difference of the methods used or, alternatively, to the low substrate concentration in our assay system.

Apparent $\mathrm{K}_{\mathrm{m}}$ 's of white blood cells were measured at $\mathrm{pH} 8.5$, which was reported to be optimum for the $K_{m}$ measurement of OTC (4). At this $\mathrm{pH}, \mathrm{K}_{\mathrm{m}}$ 's of OTC for carbamyl phosphate and for ornithine are approximately 5 and 10 times, respectively, higher in the white blood cells than those in liver. We could not afford to carry out a study to compare the OTC levels in the blood leukocytes and liver of the patient with OTC deficiency because the amount of blood sample available from the patient with OTC deficiency was limited. (For duplicate assay, at least $30 \mathrm{ml}$ of whole blood is necessary, and the patient is below 2 years of age). Snodgrass et al. (15), based on their findings, suspected that OTC in the peripheral white blood cells is different from that in the liver. This hypothesis is supported by our finding that $\mathrm{K}_{\mathrm{m}}$ 's for the enzyme in the white blood cells are not identical with those in the liver.

Our study demonstrated that the OTC activity in the granulocytes is higher than that in the mononuclear cells. Wide variations of OTC activities in the white blood cells, observed both in our study (Fig. 1) and those by Wolfe and Gatfield (17) and Snodgrass et al. (15), may be related to individual differences in the ratio of the two cell population.

Cultured lymphoid cell lines have increasingly been used in the study of the inborn errors of metabolism. With this in mind, the lymphoid cells derived from both the normal subjects and from the OTC-deficient patient were studied for OTC activity. How-

Table 2. $K_{\mathrm{m}}$ 's of ornithine transcarbamylase in human white blood cells and human liver

\begin{tabular}{|c|c|c|c|}
\hline & $\begin{array}{c}\mathrm{K}_{\mathrm{m}} \text { for ornithine } \\
(\mathrm{mM})\end{array}$ & $\begin{array}{l}K_{m} \text { for carbamyl phosphate } \\
(\mathrm{mM})\end{array}$ & Reference \\
\hline White blood cells ${ }^{* 1} 1^{2}$ & $6.7,6.2(\mathrm{pH} 8.5)^{* * * 3}$ & $0.6(\mathrm{ph} 8.5)^{* * *}$ & Present study \\
\hline Liver *1 & $0.6(\mathrm{pH} 8.5)^{* * *}$ & $0.12(\mathrm{ph} 8.5)^{* * *}$ & Present study \\
\hline Liver *2 & $0.2(\mathrm{pH} 8.5)$ & $0.2(\mathrm{ph} 8.5)$ & Heiden et al. (4) \\
\hline Liver $* 2$ & $0.8(\mathrm{ph} 8.0)$ & $0.6(\mathrm{ph} 8.0)$ & Katsunuma et al. (6) \\
\hline Liver $* * 42$ & $0.2(\mathrm{ph} 8.0)$ & $0.09(\mathrm{ph} 8.0)$ & Pierson et al. (12) \\
\hline
\end{tabular}

1 *, crude homogenate;

21 , radiochemical procedure; 2 , colorimetric procedure.

$3 * * *$, specimens from two persons.

$4 *$, purified sample. 

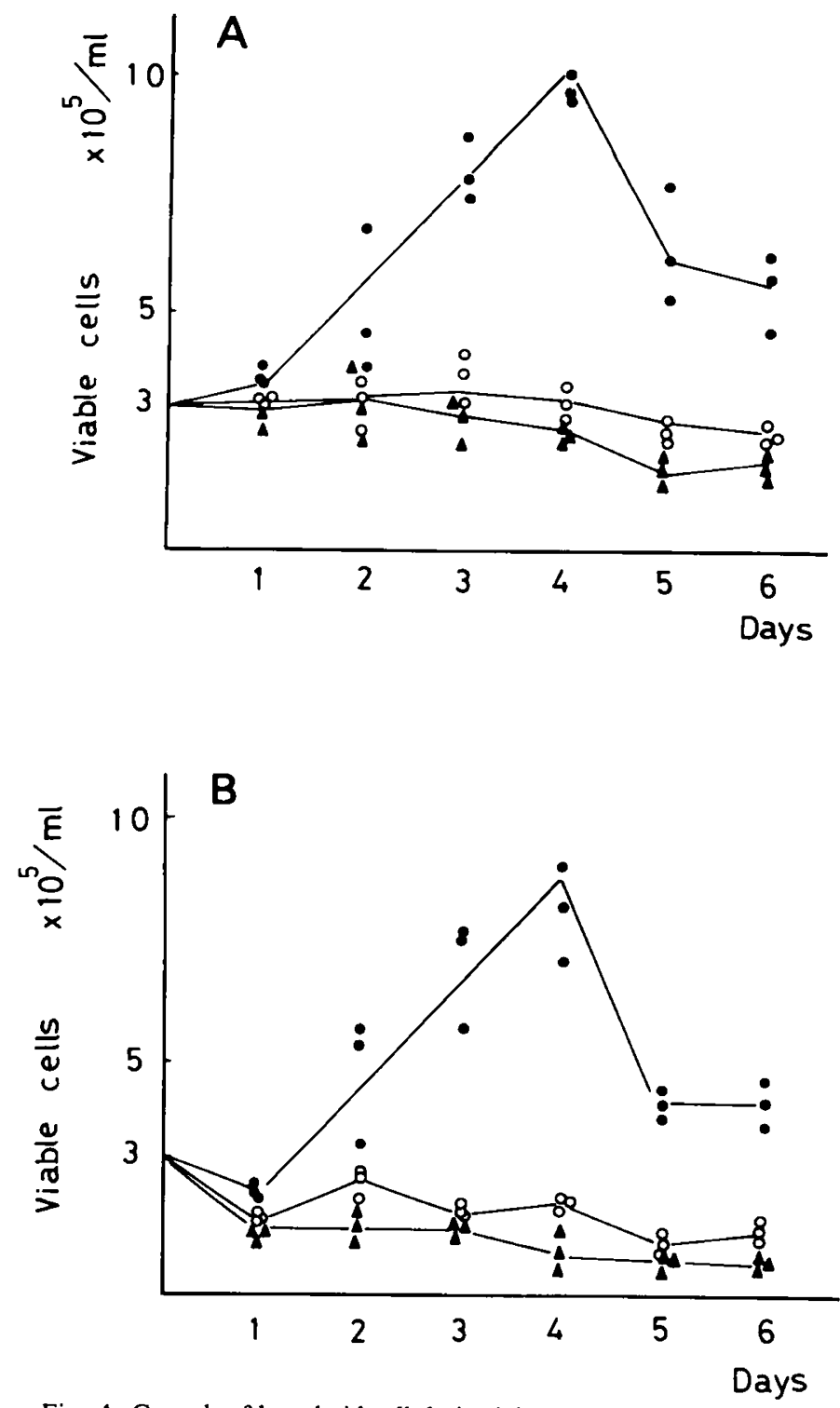

Fig. 4. Growth of lymphoid cell derived from normal subject $(A)$ and an OTC-deficient infant $(B)$ in RPMI $1640(-\infty)$ arginine $(+)$, ornithine $(-)$, or in medium with ornithine $[1 \mathrm{mM}(O) 5 \mathrm{mM}(\Delta)]$ substituted for the normally used arginine arginine $(-)$, ornithine $(+)$. Inoculations of $0.3 \times 10^{6} \mathrm{cells} / \mathrm{ml}$ were made into each of the three type of medium, and cells were incubated without medium changes.

ever, no detectable activity of the enzyme was noted in any of the lymphoid cell lines studied.

The lymphoid cells grew logarithmically in the ornithine (-) arginine $(+)$ medium, but did not grow in the ornithine $(+)$ arginine $(-)$ medium. The finding was confirmed by autoradiography, which showed no grains after incubating the lymphoid cells in the arginine (-) medium with ${ }^{14} \mathrm{C}$-ornithine, but massive grains after incubation in the arginine (-) medium with ${ }^{14} \mathrm{C}$-citrulline.

The results suggest that conversion of ornithine to citrulline is impaired, whereas that of citrulline to arginine is normal (16). The observations are compatible with those of Jacoby (5) who demonstrated that cultured human lymphoid cells do not grow in the ornithine $(+)$ citrulline $(-)$ medium. To explain the phenomenon, two possibilities may be considered: (1) OTC is missing in the EB virus-reactive B-lymphocytes, but it is lost or inactivated during the process of establishing the lymphoid cell lines. In view of the known adaptive ability of human lymphoblasts in culture $(5,16)$, the latter possibility is more likely, whereas the mechanism involved remains to be elucidated.

Reinstitution of OTC activity in established lymphoid cell lines, if it becomes possible, may pave the way to genetic therapy of OTC deficiency.

\section{REFERENCES AND NOTES}

1. Boÿum, A.: Separation of leucocytes from blood and bone marrow. Scand. J. Clin Lab Invest. Suppl.. 21: 77 (1968).

2. Brown, G. W., Jr., and Cohen, P. P.: Comparative biochemistry of urea synthesis. I. Methods for the quantitative assay of urea cycle enzymes in liver. J. Biol. Chem., 234: 1770 (1959).

3. Goldstein, A. S., Hoogeraad. N. J., Johnson, J. D., Fukunaga, K., Swierezewski, E.. Cann. H. M., and Sunshine, P.: Metabolic and genetic studies of a family with ornithine transcarbamylase deficiency. Pediatr. Res., 8 : 5 (1974).

4. Heiden. C. V.. Desplanque, J., and Bakker. H. D.: Some kinetic properties of liver ornithine carbamyl transferase (OTC) in a patient with OCT deficiency. Clin. Chim. Acta, 80: 519 (1977).

5. Jacoby, L. B.: Adaptation of cultured lymphoblasts to growth in citrulline. Exp. Cell Res., 84: 167 (1974).

6. Katsunuma, N.: (personal communication).

7. Krieger, I., Bachmann, C. Gronemeyer, W., and Cejka, J.: Propionic acidemia and hyperlysinemia in a case with ornithine transcarbamylase deficiency. $J$. Clin. Endocrinol. Metab.. 43: 796 (1976).

8. Lowry, O. H., Rosebrough, N. J., Farr, A. L., and Randall, R.: Protein measurement with the Folin phenol reagent. J. Biol. Chem., 193: 265 (1951).

9. Marshall, M., and Cohen, P. P.: Ornithine transcarbamylase from Streptococcus baecalis and bovine liver I. Isolation and subunit structure. J. Biol. Chem., 247: 1461 (1972).

10. Matsuda, I., Arashima, S.. Nambu, H.. Takekoshi, Y., and Anakura, M.: Hyperammonemia due to a mutant enzyme of ornithine transcarbamylase. Pediatrics, 48: 595 (1971).

11. Matsuda. I., Yamamoto. J., Nagata. N., Ninomiya, N., Akaboshi. I., Ohtsuka, H., and Katsuki, I.: Lysosomal enzyme activity in cultured lymphoid cell lines. Clin. Chim. Acta, 80: 483 (1977).

12. Pierson, D. L., Cox, S. L.. and Gilbert, B. E.: Human ornithine transcarbamylase. J. Biol. Chem., 252: 6464 (1977).

13. Rabier, P., Cathelineau, L., and Kamoum. P.: Letter to the Editor: Lack of mitochondrial enzymes of urea cycle in human white blood cells. Pediatr. Res., 13: 207 (1979)

14. Sinatra. F., Yoshida. T., Applebaum. M., Mason, W.. Hoogenraad, J., and Sunshine. P.: Abnormalities of carbamyl phosphate synthetase and ornithine transcarbamylase in liver of patients with Reye's syndrome. Pediatr. Res., 9. 829 (1975).

15. Snodgrass, P. J., Wappner, R. S., and Brandt, I. K.: Letter to the Editor: White cell ornithine transcarbamylase activity cannot detect the liver enzyme deficiency. Pediatr. Res., 12: 873 (1978).

16. Spector, E. B.. Lockridge. O. and Bloom. A. D.: Citrulline metabolism in normal and citrullinemia human lymphocyte lines. Biochem. Genet.. 13: 471 (1975).

17. Wolfe, D. M.. and Gatfield. P. D.: Leukocyte urea cycle enzymes in hyperammonemia. Pediatr. Res., 9: 531 (1975).

18. The authors thank Professor F. Yamashita of the Department of Pediatrics Kurume University Medical School, for his permission to examine his patien with OTC deficiency. Professor M. Tachibana of the Department of Biochemistry, Chiba University Medical School, for his kind help, and Professor T. Kaji. Department of Pediatrics, Yamaguchi University Medical School, for his discussion.

19. Requests for reprints should be addressed to: Ichiro Matsuda. M.D. Department of Pediatrics, Kumamoto University Medical School. 860 Kumamoto, Japan.

20. This research was supported by Grant-in-Aid for Scientific Research (249018) and (448229) from The Ministry of Education, Science, and Culture of Japan (Matsuda) and a Research Grant from The Ministry of Health and Welfare of Japan for the Research of Handicapped Children. 1978 (Matsuda).

21. Received for publication July 30, 1979.

22. Accepted for publication March 25, 1980. 